\title{
PROTECTIVE EFFECT OF PUMPKIN SEED OIL AGAINST LEAD ACETATE TOXICITY IN MALE MICE. BY
}

O.H. Elhamalawy

FROM

Department of Environment and Bio-Agriculture,

Faculty of Agriculture, Al-Azhar University, Cairo, Egypt.

\begin{abstract}
:
The goal of the present work was to investigate the protective effect of pumpkin seed oil (PSO) against lead acetate toxicity in male mice. lead acetate $(20 \mathrm{mg} / \mathrm{kg} \mathrm{b.w}$.) was administered orally to mice once a day for 30 successive days. Whereas, PSO was administered to the mice orally at $1.5 \mathrm{~mL} / \mathrm{kg}$ b.w. once a day for 30 successive days concurrently with treatment of lead acetate. The studied parameters were relative organs weights, DNA damage evaluation using comet assay in liver and kidney cells and micronucleus test in bone marrow and biochemical assessment of the liver and kidney function. Results showed that, lead acetate caused DNA damage in tested cells and significant increase in the levels of biochemical measurements. In contrast, PSO administration plus lead acetate effectively alleviated DNA damage in tested cells and improved the biochemical alterations. It can be concluded that PSO may has a protective role against lead acetate toxicity in male mice.
\end{abstract}

Key words:

Pumpkin seed oil; lead acetate; DNA damage; Micronucleus; Comet assay; Biochemical measurements.

\section{Introduction}

In both developing and industrialized countries, environmental and occupational lead pollution is a common problem and may contribute to multi-organ toxicity in man and animals (El-Tantawy, 2016; Mohammed et al., 2017).

Lead is a naturally occurring bluish-gray metal found in small amounts in the Earth's crust and can be found in all parts of our environment (Gupta, 2007). It is found in our food, water, air and soil. In addition, it is emitted by smelters and boilers that burn used motor oil and is frequently deposited in the soil, where it is taken up by crops (Chiras, 2009).

Lead is known as an enzymatic toxicant, neurotoxic, hemato and cardiovascular toxic, nephrotoxic, hepatotoxic, immunotoxic, carcinogenic, teratogenic and mutagenic (Kiran et al., 2009; Falck et al., 2015). Lead can readily be absorbed by intestine, lung and less commonly through the skin. Almost $90 \%$ of absorbed lead binds to albumin (Gonick, 2011). Through endocytosis and/or Erythrophagocytosis, it locates into different tissues and organs including liver and kidney where it exhibits oxidative damage on cells and tissue, and cellular organelles (Reyes et al., 2013; Kwon et al., 2015). Kidney is one of targeted site of lead toxicity for being major route of excretion from body and facilitates kidney damage via oxidative stress and lipid peroxidation (Garçon et al., 2007; El-Nekeety et al., 2009). 
Pumpkin (Cucurbita pepo) is a leafy green vegetable; it belongs to the Cucurbitaceae family. Pumpkin seeds are considered as a suitable source of edible oil. Pumpkin seed oil (PSO) has many antioxidants and beneficial nutritional supplements. PSO contains high amounts of vitamin $E$ and tocoferol (Stevenson et al., 2007). It also contains considerable amounts of palmitic (C 16:0), stearic (C 18:0), oleic (C 18:1) and linoleic (C 18:2) (Kulaitiene et al., 2007). Moreover, it contains phenolic compounds such as tyrosol, vanillic acid, vanillin, ferulic acid, and luteolin (Andjelkovic et al., 2010). In addition, it is rich in amino acids, phytosterols, $\beta$-carotenes and selenium (Procida et al., 2012).

Therefore, the present work aimed to evaluate the deleterious effects of lead acetate on relative organs weights, DNA integrity in liver, kidney and femoral bone marrow; and biochemical measurements of male mice and the protective effects of PSO on these parameters.

\section{Materials and Methods}

\section{Chemicals:}

Lead acetate was purchased from Sigma-Aldrich Company (St. Louis, MO, USA). Pumpkin seed commercial oil (PSO) was purchased from EL Captin Company (Al Obour City, Cairo, Egypt). All other chemicals were of analytical grade and purchased from standard commercial suppliers.

\section{Animals:}

Male Swiss albino mice $(26 \pm 5 \mathrm{~g})$ were purchased from Theodor Bilharz Research Institute, Giza, Egypt, at 10-12 weeks of age. Animals were housed in polypropylene cages $(43 \mathrm{~cm} \times 30 \mathrm{~cm} \times 15 \mathrm{~cm}$, five mice per cage $)$ with stainless steel covers in the Animal House of Environment and Bio-agriculture Department, Faculty of Agriculture, Al-Azhar University. Animals were kept under controlled temperature $\left(23 \pm 4{ }^{\circ} \mathrm{C}\right), 50-55 \%$ relative humidity and a photoperiod of $12 \mathrm{~h}$ light : $12 \mathrm{~h}$ dark cycle. Food and water were given ad libitum. Animals received human care in compliance with the guidelines of the Animal Care and Use Committee of the National Institutes of Health (NIH publication 86-23 revised 1985). Animals were allowed to adapt to their surrounding environment for 2 weeks prior to the start of the experiments.

\section{Experimental design:}

Forty animals were randomly divided into four groups $(\mathrm{n}=10)$ and orally administered for 30 successive days with lead acetate and/or PSO.

Experimental groups were as follows: Control group: animals were orally administered with saline. PSO group: animals were orally administered with PSO at dose of $1.5 \mathrm{~mL} / \mathrm{kg}$ b.w. (Ali and Abdelzaher, 2017). Lead acetate group: animals were orally administered with lead acetate at dose of $20 \mathrm{mg} / \mathrm{kg}$ b.w. (Aldahmash and ElNagar, 2016). PSO plus lead group: animals were orally administered with $1.5 \mathrm{~mL} / \mathrm{kg}$ b.w. PSO concurrently with lead acetate $(20 \mathrm{mg} / \mathrm{kg} \mathrm{b.w.)}$.

\section{Relative organs weights:}

At the termination of the experiments, internal organs such as liver and kidney were dissected out, trimmed of excess fat and weighted. The organs weight was presented as relative organ weight as follows: 
Relative organ weight $=\underline{\text { Absolute organ weight }(\mathrm{g})} \times 100$

Final body weight $(\mathrm{g})$

\section{Evaluation of DNA damage:}

\section{Comet assay in liver and kidney cells:}

The comet assay was performed in liver and kidney cells according to Bandyopadhyaya et al. (2008). Briefly, $50 \mu \mathrm{L}$ of cell suspension was mixed with 100 $\mu \mathrm{L}$ of $1 \%$ low melting point (LMP) agarose and added to fully frosted slides coated with $80 \mu \mathrm{L}$ of $1 \%$ normal melting point (NMP) agarose. The cells were then incubated in a lysis solution $\left(2.5 \mathrm{~mol} \mathrm{~L}^{-1} \mathrm{NaCl}, 100 \mathrm{mmol} \mathrm{L}^{-1}\right.$ EDTA, $10 \mathrm{mmol} \mathrm{L}{ }^{-1}$ Tris-HCL, $1 \%$ Triton $\mathrm{X}-100, \mathrm{pH} 10)$ at $4{ }^{\circ} \mathrm{C}$ for at least $2 \mathrm{~h}$, at which the slides were placed into an alkaline solution (300 mmol L-1 $\left.\mathrm{NaOH}, 1 \mathrm{mmol} \mathrm{L}^{-1} \mathrm{EDTA}, \mathrm{pH} 13\right)$ at $4{ }^{\circ} \mathrm{C}$ for $20 \mathrm{~min}$ so as to allow DNA unwinding, and electrophoresed at $25 \mathrm{~V}(300 \mathrm{~mA})$ for $20 \mathrm{~min}$. Finally, the slides were neutralized in a $400 \mathrm{mmol} \mathrm{L}^{-1}$ Tris buffer $(\mathrm{pH} \mathrm{7.5)}$ for $15 \mathrm{~min}$ and stained with ethidium bromide $\left(5 \mu \mathrm{g} \mathrm{mL}{ }^{-1}\right)$. Images of 50 randomly selected nuclei per experimental group were captured using a fluorescence microscope (Eclipse 800, Nikon, Tokyo, Japan) and analyzed with image analysis software (Comet Assay IV, Perceptive Instruments, Suffolk, UK). Scored parameters included tail length, DNA percentage in tail and Olive tail moment (OTM). Tail length is the maximum distance that the damaged DNA migrates from the centre of the cell nucleus. DNA Percentage in tail is the DNA content that migrates from the nucleus into the comet tail. OTM is the product of the tail length and percentage DNA, which gives a more integrated measurement of overall DNA damage in the cell.

\section{Bone marrow micronucleus assay:}

The micronucleus (MN) test was carried out in mice femoral bone marrow cells according to Chauhan et al. (2000). Numbers of normochromatic, polychromatic erythrocytes and micronuclei were evaluated in control and treated groups. For micronuclei evaluation, 2000 polychromatic erythrocytes were scored per animal. Both normochromatic erythrocytes (NCEs) and polychromatic erythrocytes (PCEs) were scored in 500 erythrocytes for determination of the PCEs: NCEs ratio according to the OECD No. 474 guideline of mammalian erythrocyte micronucleus test for chemicals testing (OECD, 1997).

\section{Biochemical analysis:}

\section{Liver function investigation:}

Serum aspartate aminotransferase (AST) and alanine aminotransferase (ALT) activities were determined by using kits obtained from Biodiagnostic (Egypt) according to the method of Reitman and Frankel (1957). Serum alkaline phosphatase (ALP) was determined by using kits obtained from Biodiagnostic (Egypt) according to the method of Belfield and Goldberg (1971).

\section{Kidney function investigation:}

Serum creatinine, urea and uric acid were assayed spectrophotometrically using kits provided from Biodiagnostic Co. (Egypt). 


\section{Statistical analysis:}

Statistical analyses were performed with SPSS 16 software. Experimental data were analyzed using one-way analysis of variance (ANOVA). Duncan's multiple range tests was used to determine the significant differences between means. All values expressed as mean \pm SD and the significance level was set at $P \leq 0.05$.

\section{Results and discussion}

\section{Relative organs weights:}

The relative weight of liver and kidney of the male mice treated with lead acetate and/or PSO are summarized in Table 1. Oral administration of lead acetate to male mice at a dose of $20 \mathrm{mg} / \mathrm{kg}$ b.w. for 30 consecutive days induced a significant loss $(p \leq 0.05)$ in the relative weights of liver $(3.34 \pm 0.04)$ and kidney $(1.56 \pm 0.03)$ as compared to control $(3.39 \pm 0.05$ and $1.62 \pm 0.03)$, respectively. In contrast, oral administration of PSO plus lead acetate produced a significant increase $(P \leq 0.05)$ in the relative weights of liver $(3.38 \pm 0.02)$ and kidney $(1.61 \pm 0.02)$ compared with lead acetate treated male mice.

These results are in coincidence with the findings of Abdel-Moniem et al. (2011) they found that exposure to lead acetate $(20 \mathrm{mg} / \mathrm{kg})$ reduced the body and kidney weight of male rats. Balubaid (2011) demonstrated that pumpkin extract ameliorated the highly significant decrease in the infant body weights of mice treated with haloperidol drug. Hashemi (2013) reported that pretreatment with PSO increased the weight of testes in sodium valproate's treated rats. Al-Masri (2015) revealed that PSO produced a significant protection against lead induced reduction in body weight of male rats. In addition, Eissa et al. (2018) found that oral administration of PSO for 28 successive days either before, with or after treatment of bisphenol-A significantly elevated the relative weights of liver and testes compared with the bisphenol-A treated male mice.

The protective role of PSO against the adverse effects of lead acetate on relative organs weights could be due to its content of various bioactive compounds such as magnesium, phosphorus, manganese, copper, iron and zinc which are vital in growth (Alan, 2006).

Table (1): Relative organs weights of treated male mice with lead acetate and/or pumpkin seed oil (PSO) for 30 consecutive days.

\begin{tabular}{|l|c|c|}
\hline \multirow{2}{*}{ Groups } & \multicolumn{2}{|c|}{ Relative organs weights (g) } \\
\cline { 2 - 3 } & \multicolumn{1}{c|}{ Liver } & Kidney \\
\hline Control & $3.39 \pm 0.05^{\mathrm{a}}$ & $1.62 \pm 0.03^{\mathrm{a}}$ \\
\hline PSO (1.5 $\mathbf{~ m L / k g ) ~}$ & $3.41 \pm 0.02^{\mathrm{a}}$ & $1.63 \pm 0.02^{\mathrm{a}}$ \\
\hline Lead acetate (20 $\mathbf{~ m g / k g ) ~}$ & $3.34 \pm 0.04^{\mathrm{c}}$ & $1.56 \pm 0.03^{\mathrm{c}}$ \\
\hline PSO plus lead acetate & $3.38 \pm 0.02^{\mathrm{ab}}$ & $1.61 \pm 0.02^{\mathrm{ab}}$ \\
\hline
\end{tabular}

Data are expressed as means \pm SD. Mean values in the same column within each parameter bearing the same superscript do not differ significantly $(P \leq 0.05)$. 


\section{DNA damage evaluation:}

In the present study, DNA damage was evaluated by comet assay in liver and kidney cells and by micronucleus assay in femoral bone marrow cells. The alkaline comet assay was used as a quantitative and visual method to measure DNA strand breaks that can be applied directly to cells (Gedik $\boldsymbol{e t}$ al., 1998). DNA damage is an important initial event in carcinogensis. DNA lesions can change in nucleotide sequence, causing mutagenesis and other cellular mechanisms (Lord and Ashworth 2012). Results of comet assay showed that the exposure to lead acetate caused an increase in DNA strand breaks leading to greater DNA migration out of the nucleus into the tail of the comet in mice liver and kidney cells.

\section{Comet assay in liver cells:}

The comet assay results of liver cells are illustrated in Table 2 . Lead acetate induced significant increase $(P \leq 0.05)$ in the mean values of tailed cells $(30.77 \pm 0.59)$, tail length (18.16 \pm 0.47$)$, percentage of tail DNA (21.34 \pm 0.54$)$ and olive tail moment $(3.88 \pm 0.17)$ in liver cells as compared to control $(12.86 \pm 0.54,8.22 \pm 0.96,13.32 \pm 0.24$ and $1.09 \pm 0.03$ ), respectively. In contrary, administration of male mice with PSO plus lead acetate diminished significantly $(P \leq 0.05)$ the increase in the mean values of comet parameters induced by lead acetate in liver cells.

Table (2): Comet assay parameters in liver cells of treated male mice with lead acetate and/or pumpkin seed oil (PSO) for 30 consecutive days.

\begin{tabular}{|l|c|l|l|l|l|}
\hline Groups & $\begin{array}{c}\text { Intact } \\
\text { cells } \\
(\%)\end{array}$ & $\begin{array}{c}\text { Tailed cells } \\
(\%)\end{array}$ & $\begin{array}{c}\text { Tail length } \\
(\boldsymbol{\mu m})\end{array}$ & $\begin{array}{c}\text { Tail DNA } \\
(\%)\end{array}$ & $\begin{array}{c}\text { Olive tail } \\
\text { moment } \\
(\boldsymbol{\mu m})\end{array}$ \\
\hline Control & $87.14 \pm 0.54^{\mathrm{b}}$ & $12.86 \pm 0.54 \mathrm{~b}$ & $8.22 \pm 0.96^{\mathrm{c}}$ & $13.32 \pm 0.24^{\mathrm{c}}$ & $1.09 \pm 0.03^{\mathrm{c}}$ \\
\hline $\begin{array}{l}\text { PSO }(\mathbf{1 . 5} \\
\mathbf{m L} / \mathbf{k g})\end{array}$ & $88.16 \pm 0.26^{\mathrm{a}}$ & $11.84 \pm 0.26^{\mathrm{c}}$ & $8.58 \pm 0.25^{\mathrm{c}}$ & $12.79 \pm 0.14^{\mathrm{c}}$ & $1.10 \pm 0.02^{\mathrm{c}}$ \\
\hline $\begin{array}{l}\text { Lead acetate } \\
(\mathbf{2 0} \mathbf{m g} / \mathbf{k g})\end{array}$ & $69.23 \pm 0.59^{\mathrm{c}}$ & $30.77 \pm 0.59^{\mathrm{a}}$ & $18.16 \pm 0.47^{\mathrm{a}}$ & $21.34 \pm 0.54^{\mathrm{a}}$ & $3.88 \pm 0.17^{\mathrm{a}}$ \\
\hline $\begin{array}{l}\text { PSO plus } \\
\text { lead acetate }\end{array}$ & $86.57 \pm 0.55^{\mathrm{b}}$ & $13.43 \pm 0.55^{\mathrm{b}}$ & $9.40 \pm 0.41^{\mathrm{b}}$ & $14.43 \pm 0.33^{\mathrm{b}}$ & $1.35 \pm 0.09^{\mathrm{b}}$ \\
\hline
\end{tabular}

Data are expressed as means \pm SD. Mean values in the same column within each parameter bearing the same superscript do not differ significantly $(P \leq 0.05)$.

\section{Comet assay in kidney cells:}

As shown in Table 3, a significant increase $(P \leq 0.05)$ in the values of tailed cell percentage $(32.83 \pm 0.64)$, tail length $(17.45 \pm 0.48)$, tail DNA percentage $(19.22 \pm 0.66)$ and olive tail moment $(3.35 \pm 0.19)$ was observed in kidney cells of male mice treated with lead acetate compared to control $(11.67 \pm 0.25,8.35 \pm 0.34,12.29 \pm 0.35$ and $1.03 \pm 0.04)$, respectively. On the other hand, administration of male mice with PSO plus lead acetate inhibited significantly $(P \leq 0.05)$ the increase in the mean values of tailed 
cells percentage $(14.85 \pm 0.21)$, tail length $(12.31 \pm 0.58)$, DNA tail percentage $(14.78 \pm 0.51)$ and olive tail moment $(1.81 \pm 0.52)$ in kidney cells compared to those caused by lead acetate.

\section{Micronucleus test:}

Micronuclei $(\mathrm{MN})$ are cytoplasmic chromatin masses with the appearance of small nuclei that arise from chromosome fragments of intact whole chromosome lagging behind at the anaphase stage of cell division. They formed due to damaging effects on the spindle, centromere/centromere-associated proteins, or acentric chromosomes due to the clastogenic action and can be recognized in the cytoplasm of immature polychromatic erythrocytes (Naik and Vijayalaxmi, 2009).

According to the data in Table 4, oral administration of lead acetate significantly increased $(P \leq 0.05)$ the mean values of MNPCEs $(55.50 \pm 5.19)$ compared to control (9.75 \pm 1.71$)$. In contrast, oral administration of PSO plus lead acetate decreased significantly $(P \leq 0.05)$ the mean value of MNPCEs $(22.25 \pm 4.99)$ in bone marrow cells. In addition, cytotoxicity evaluation of bone marrow erythrocytes showed that lead acetate caused significant reduction $(P \leq 0.05)$ in the ratio of PCEs/NCEs $(1.32 \pm 0.03)$ as compared to control $(2.57 \pm 0.08)$. While, PSO has protection against lead acetate cytotoxicity. This protection was appeared in the elevation of the PCEs/NCEs ratio $(2.17 \pm 0.07)$ as compared with those of lead acetate treated group.

Table (3): Comet assay parameters in kidney cells of treated male mice with lead acetate and/or pumpkin seed oil (PSO) for 30 consecutive days.

\begin{tabular}{|l|c|c|c|c|c|}
\hline Groups & $\begin{array}{c}\text { Intact } \\
\mathbf{c e l l s} \\
(\boldsymbol{\%})\end{array}$ & $\begin{array}{c}\text { Tailed cells } \\
(\boldsymbol{\%})\end{array}$ & $\begin{array}{c}\text { Tail length } \\
(\boldsymbol{\mu m})\end{array}$ & $\begin{array}{c}\text { Tail DNA } \\
(\%)\end{array}$ & $\begin{array}{c}\text { Olive tail } \\
\text { moment } \\
(\boldsymbol{\mu m})\end{array}$ \\
\hline Control & $88.33 \pm 0.25^{\mathrm{a}}$ & $11.67 \pm 0.25^{\mathrm{c}}$ & $8.35 \pm 0.34^{\mathrm{c}}$ & $12.29 \pm 0.35^{\mathrm{c}}$ & $1.03 \pm 0.04^{\mathrm{c}}$ \\
\hline $\begin{array}{l}\text { PSO } \mathbf{( 1 . 5} \\
\mathbf{m L} / \mathbf{k g})\end{array}$ & $88.32 \pm 0.38^{\mathrm{a}}$ & $11.68 \pm 0.38^{\mathrm{c}}$ & $8.82 \pm 0.35^{\mathrm{c}}$ & $12.50 \pm 0.29^{\mathrm{c}}$ & $1.10 \pm 0.07^{\mathrm{c}}$ \\
\hline $\begin{array}{l}\text { Lead acetate } \\
(\mathbf{2 0} \mathbf{~ m g} / \mathbf{k g})\end{array}$ & $67.17 \pm 0.64^{\mathrm{c}}$ & $32.83 \pm 0.64^{\mathrm{a}}$ & $17.45 \pm 0.48^{\mathrm{a}}$ & $19.22 \pm 0.66^{\mathrm{a}}$ & $3.35 \pm 0.19^{\mathrm{a}}$ \\
\hline $\begin{array}{l}\text { PSO plus } \\
\text { lead acetate }\end{array}$ & $85.15 \pm 0.21^{\mathrm{b}}$ & $14.85 \pm 0.21^{\mathrm{b}}$ & $12.31 \pm 0.58^{\mathrm{b}}$ & $14.78 \pm 0.51^{\mathrm{b}}$ & $1.81 \pm 0.52^{\mathrm{b}}$ \\
\hline
\end{tabular}

Data are expressed as means \pm SD. Mean values in the same column within each parameter bearing the same superscript do not differ significantly $(P \leq 0.05)$.

Our results indicated that the lead acetate oral administration for 30 successive days showed DNA damage activity in tested cells. These results came to a consensus with Abdel-Moniem et al. (2010) they found that exposure to lead acetate $(20 \mathrm{mg} / \mathrm{kg})$ induced DNA fragmentation in male rats. Azoz and Raafat (2012) demonstrated that 
treatment of rats with lead acetate at a dose of $0.5 \mathrm{~g} / 100 \mathrm{ml}$ drinking water for 2 months caused a significant increases in the percent of multinucleated polychromatic erythrocytes (MNPCEs).

Table (4): Frequencies of micronucleated polychromatic erythrocytes and polychromatic/normochromatic ratio in bone marrow cells of lead acetate and/or pumpkin seed oil (PSO) treated male mice for 30 consecutive days.

\begin{tabular}{|l|c|c|c|c|}
\hline Groups & MNPCEs & PCEs & NCEs & $\begin{array}{c}\text { PCEs/NCEs } \\
\text { ratio }\end{array}$ \\
\hline Control & $9.75 \pm 1.71^{\mathrm{c}}$ & $1439.25 \pm 13.59^{\mathrm{a}}$ & $560.75 \pm 13.59^{\mathrm{c}}$ & $2.57 \pm 0.08^{\mathrm{a}}$ \\
\hline $\begin{array}{l}\text { PSO (1.5 } \\
\text { mL/kg) }\end{array}$ & $8.50 \pm 1.73^{\mathrm{c}}$ & $1460.50 \pm 19.12^{\mathrm{a}}$ & $539.50 \pm 19.12^{\mathrm{c}}$ & $2.61 \pm 0.13^{\mathrm{a}}$ \\
\hline $\begin{array}{l}\text { Lead } \\
\text { acetate (20 } \\
\text { mg/kg) }\end{array}$ & $55.50 \pm 5.19^{\mathrm{a}}$ & $1136.50 \pm 13.30^{\mathrm{c}}$ & $863.50 \pm 13.30^{\mathrm{a}}$ & $1.32 \pm 0.03^{\mathrm{c}}$ \\
\hline $\begin{array}{l}\text { PSO plus } \\
\text { lead } \\
\text { acetate }\end{array}$ & $22.25 \pm 4.99^{\mathrm{b}}$ & $1370.00 \pm 14.25^{\mathrm{b}}$ & $630.00 \pm 14.25^{\mathrm{b}}$ & $2.17 \pm 0.07^{\mathrm{b}}$ \\
\hline
\end{tabular}

Data are expressed as means \pm SD. Mean values in the same column within each parameter bearing the same superscript do not differ significantly $(P \leq 0.05)$. MNPCEs: Micronucleated Polychromatic erythrocytes PCEs: Ploychromatic erythrocitesNCEs: Normochromatic erythrocytes.

The mechanism of lead acetate genotoxicity might work through the induction of oxidative stress. Oxidative DNA damage by free radicals is a common mechanism of lead toxicity (Valko et al., 2006; Sharma et al., 2014). Reactive oxygen species (ROS) damage DNA either directly (e.g. via oxidation of bases) or indirectly via interactions with biologically relevant molecules, e.g. via oxidation of fatty acids in cell membranes (Knasmuller et al., 2008). Additionally, they destroy also repair enzymes, DNA polymerases and microtubule (Halliwell, 2007).

Furthermore, it was shown in in vitro studies with cultured mammalian cells that lead binds to zinc-finger proteins including histones and protamines which are involved in the protection of DNA (Koedrith and Seo, 2011). In addition, several studies were published which indicate that the metal interferes with DNA-repair mechanisms (Hartwig et al., 1990; Hartwig, 1994).

Another relevant mechanism which may lead to DNA damage by lead acetate is an increase of cell proliferation. Increased proliferative lesions were found in experiments with rats and mice, i.e. in the proximal tubular epithelium in the kidneys after i.p. administration of lead acetate (National Toxicology Program, 2003). Also in experiments with hepatectomized rats, increased mitogenic activity was observed in the liver tissue when the animals were treated with lead nitrate (National Toxicology Program, 2003). In none of these experiments DNA damage was monitored in parallel in the respective tissues. 
Regarding PSO treatment that alleviated the lead acetate induction of DNA damage in tested cells, these results came to a consensus with Elfiky et al. (2012) they found that oral administration of PSO for ten consecutive days either before or after treatment of azathioprine was effective in the reduction of DNA fragmentation and MNPCEs frequencies, meanwhile, improved the PCEs/NCEs ratio. Ali and Abdelzaher (2017) found that treatment with $1.5 \mathrm{~mL} / \mathrm{kg} / \mathrm{day}$ PSO for 5 weeks to sodium nitrite's treated rats significantly alleviated DNA damage and chromosomal abnormalities. In addition, Abou-Zeid et al. (2018) demonstrated that PSO was effective in reducing the oxidative stress, apoptosis and the percentage of DNA fragmentation in both liver and kidney of emamectin-treated mice. Eissa et al. (2018) revealed that PSO administration to male mice for 28 successive days either before, with or after treatment of bisphenol-A alleviated significantly the induction of DNA damage in liver, testes and femoral bone marrow cells as a result to bisphenol-A exposure.

Therefore, it might suggest that the protecting effects of PSO against lead acetate genotoxicity could be due to their content of varied bioactive compounds such as vitamin E and phenolic compounds (Eissa et al., 2018). Phenolic compounds have antioxidant, anti-mutagenic, anticarcinogenic and anti-inflammatory properties that might be beneficial in protecting the genome stability (Xie et al., 2013). In the same manner, polyphenolics ameliorate cell injury and protect oxidant induced DNA from lesion by reducing the free radical mediated oxidative damage (Urquiaga and Leighton, 2000). Furthermore, vitamin $\mathrm{E}$ has an antioxidant role and can contribute to the cells protection against the free radicals deleterious property (Santana et al., 2015).

In addition to the presence of phenolic compounds and vitamin $\mathrm{E}$, selenium in the composition of PSO incorporated into the structure of the glutathione peroxidase enzyme, and directly related to its antioxidant activity (Al- Zuhair et al., 1997; Fruhwirth and Hermetter, 2007; Zadak et al., 2009). Moreover, PSO is rich in $\beta$ carotene that is a potent free radical quencher, singlet scavenger, and lipid antioxidant (Fruhwirth and Hermetter, 2007). Also, the phytosterols in the structure of PSO are reported to have antioxidant effects (Fruhwirth and Hermetter, 2007; Nyam et al., 2009).

\section{Biochemical Analysis:}

\section{Liver function investigation:}

According to data in Table 5, a significant increase $(P \leq 0.05)$ in the mean values of ALT (43.37 \pm 2.61$)$, AST (49.66 \pm 2.08$)$ and ALP (128.00 \pm 5.61$)$ was observed following the treatment with lead acetate for 30 successive days compared with control $(25.33 \pm 1.15,29.67 \pm 1.52$ and $60.00 \pm 2.65)$, respectively. While, oral administration of PSO plus lead acetate produced a significant amelioration $(P \leq 0.05)$ in the levels of ALT (31.00 \pm 1.16$)$, AST $(34.31 \pm 1.43)$ and ALP $(82.33 \pm 4.16)$ compared with lead acetate treated alone. 
Table (5): Changes in the levels of ALT, AST and ALP in serum of male mice treated with lead acetate and/or pumpkin seed oil (PSO) for 30 consecutive days.

\begin{tabular}{|l|c|c|c|}
\hline Groups & $\begin{array}{c}\text { ALT } \\
(\mathbf{U} / \mathbf{L})\end{array}$ & $\begin{array}{c}\text { AST } \\
(\mathbf{U} / \mathbf{L})\end{array}$ & $\begin{array}{c}\text { ALP } \\
(\mathbf{U} / \mathbf{L})\end{array}$ \\
\hline Control & $25.33 \pm 1.15^{\mathrm{c}}$ & $29.67 \pm 1.52^{\mathrm{c}}$ & $60.00 \pm 2.65^{\mathrm{c}}$ \\
\hline PSO $(\mathbf{1 . 5} \mathbf{~ m L / k g )}$ & $24.29 \pm 1.52^{\mathrm{c}}$ & $28.33 \pm 1.56^{\mathrm{c}}$ & $54.00 \pm 3.00^{\mathrm{d}}$ \\
\hline $\begin{array}{l}\text { Lead acetate } \mathbf{( 2 0} \\
\text { mg/kg) }\end{array}$ & $43.37 \pm 2.61^{\mathrm{a}}$ & $49.66 \pm 2.08^{\mathrm{a}}$ & $128.00 \pm 5.61^{\mathrm{a}}$ \\
\hline PSO plus lead acetate & $31.00 \pm 1.16^{\mathrm{b}}$ & $34.31 \pm 1.43^{\mathrm{b}}$ & $82.33 \pm 4.16^{\mathrm{b}}$ \\
\hline
\end{tabular}

Data are expressed as means \pm SD. Mean values in the same column within each parameter bearing the same superscript do not differ significantly $(P \leq 0.05)$.

\section{kidney function investigation:}

As illustrated in Table 6, oral administration of lead acetate caused a significant rise in the levels of creatinine $(2.43 \pm 0.25)$, urea $(52.00 \pm 4.00)$ and uric acid $(7.73 \pm 0.42)$ as compared to control group $(0.93 \pm 0.15,21.66 \pm 2.31$ and $3.66 \pm 0.21)$, respectively. On the other hand, administration of male mice with PSO plus lead acetate diminished significantly $(P \leq 0.05)$ the increase in the levels of creatinine $(1.42 \pm 0.15)$, urea $(31.33 \pm 2.52)$ and uric acid $(4.76 \pm 0.35)$ by lead acetate treatment.

Table (6): Changes in the levels of creatinine, urea and uric acid in serum of male mice treated with lead acetate and/or pumpkin seed oil (PSO) for 30 consecutive days.

\begin{tabular}{|l|c|c|c|}
\hline Groups & $\begin{array}{c}\text { Creatinine } \\
(\mathbf{m g} / \mathbf{d l})\end{array}$ & $\begin{array}{c}\text { Urea } \\
(\mathbf{m g} / \mathbf{d l})\end{array}$ & $\begin{array}{c}\text { Uric acid } \\
(\mathbf{m g} / \mathbf{d l})\end{array}$ \\
\hline Control & $0.93 \pm 0.15^{\mathrm{c}}$ & $21.66 \pm 2.31^{\mathrm{c}}$ & $3.66 \pm 0.21^{\mathrm{c}}$ \\
\hline PSO $\mathbf{( 1 . 5} \mathbf{~ m L / k g )}$ & $0.83 \pm 0.05^{\mathrm{c}}$ & $20.62 \pm 2.08^{\mathrm{c}}$ & $3.36 \pm 0.25^{\mathrm{c}}$ \\
\hline $\begin{array}{l}\text { Lead acetate } \mathbf{( 2 0} \\
\mathbf{m g} / \mathbf{k g})\end{array}$ & $2.43 \pm 0.25^{\mathrm{a}}$ & $52.00 \pm 4.00^{\mathrm{a}}$ & $7.73 \pm 0.42^{\mathrm{a}}$ \\
\hline PSO plus lead acetate & $1.42 \pm 0.15^{\mathrm{b}}$ & $31.33 \pm 2.52^{\mathrm{b}}$ & $4.76 \pm 0.35^{\mathrm{b}}$ \\
\hline
\end{tabular}

Data are expressed as means \pm SD. Mean values in the same column within each parameter bearing the same superscript do not differ significantly $(P \leq 0.05)$.

The biochemical alterations induced by lead acetate are in agreement with the findings of Suleman et al. (2011) they found that ALT, creatinine and uric acid levels were increased significantly in broiler chickens exposed to lead acetate. Abdel-Moniem et al. (2011) reported that treatment of rats with lead acetate $(20 \mathrm{mg} / \mathrm{kg})$ significantly elevated the level of uric acid, blood nitrogen urea and creatinine as markers of kidney function. Azoz and Raafat (2012) revealed that treatment of rats with lead acetate at a dose of $0.5 \mathrm{~g} / 100 \mathrm{ml}$ drinking water for 2 months caused a significant increases in serum AST, ALT and ALP. 
Serum levels of liver enzymes such as AST and ALT commonly used as an indicator of liver damage or disease (Kodai et al., 2007; Campo et al., 2008; Liu et al., 2013). Of the two, ALT thought to be more specific for hepatic injury because it is present mainly in liver cytosole and in low concentration elsewhere (Giboney, 2005). When the liver hepatocytes damaged, these enzymes are released into the blood where the significant increase in AST and ALT activities indicates the damage to the cytosole and mitochondria (Mathuria and Verma, 2008). Gaskill et al, (2005) reported that the high plasma AST and ALT are accompanied by high liver microsomal membrane fluidity, free radical generation and alteration in the liver tissue.

The protective role of PSO are in agreement with those obtained by Abou Seif et al. (2014) they found that the pre-treatment with PSO successfully ameliorated the elevated activities of ALT and ALP by alcohol treatment. Moreover, Al-Okbi et al. (2014) reported that PSO administration with high fructose diet (HFD) resulted in significant reduction of ALT and AST activity.

The improvement in biochemical alterations alterations afforded by PSO may be attributed to their high content of the polyunsaturated fatty acids (PUFAs). Membrane incorporation of PUFAs may reduce cellular susceptibility to lipid peroxidation and alter membrane fluidity (Best et al., 2003; Eissa et al. 2018). Moreover, PSO is also rich in zinc which plays an important role in the structure of proteins and cell membranes and protect against damage (Bataineh et al., 2002).

\section{Conclusion:}

It can be concluded that lead acetate has the potential to produce genotoxic effects and biochemical alterations in male mice. Accordingly, strict limitations on the use of this compound must be put. PSO appears to have abundant beneficial properties for applications in food. The content of compounds such as polyunsaturated fatty acids, essential amino acids, vitamin E, selenium and polyphenols makes PSO a supply to satisfy essential needs in human diet and health maintenance. Data illustrated that PSO can used as therapeutic agent to attenuate the deleterious effects of lead acetate. Subsequently, it can be categorized as edible oil with a high potential of antioxidant activity.

\section{REFERENCES:}

Abdel-Moniem, A.E., Dkhil, M.A. and Al-Quraishy, S. (2010). Protective role of flaxseed oil against lead acetate induced oxidative stress in testes of adult rats. African Journal of Biotechnology, 9(42): 7216-7223.

Abdel-Moneim, A.E., Dkhil, M.A. and Al-Quraishy, S. (2011). The potential role of flaxseed oil on lead acetate induced kidney injure in adult male albino rats. African Journal of Biotechnology, 10(8): 1436-1451.

Abou Seif, H.S. (2014). Ameliorative effect of pumpkin oil (Cucurbita pepo L.) against alcohol-induced hepatotoxicity and oxidative stress in albino rats. Journal of Basic and Applied Sciences, 3: 178-185.

Abou-Zeid, S.M., AbuBakrb, H.O., Mohamedc, M.A. and El-Bahrawyd, A. (2018). Ameliorative effect of pumpkin seed oil against emamectin induced toxicity in mice. Biomedicine and Pharmacotherapy, 98: 242-251. 
Alan, R.G. (2006). The natural pharmacy benefits of pumpkin oil 3rd Edition. 220225.

Aldahmash, B.A. and El-Nagar, D.M. (2016). Antioxidant effects of captopril against lead acetate-induced hepatic and splenic tissue toxicity in Swiss albino mice. Saudi Journal of Biological Sciences, 23: 667-673.

Ali, D.M. and Abdelzaher, W.Y. (2017). Possible protective effect of pumpkin seed oil against sodium nitrite in rats; a biochemical and genetic study. International Journal of Clinical Pharmacology and Toxicology, 6(2): 262-269.

Al-Masri, S.A. (2015). Effect of pumpkin oil and vitamin E on lead induced testicular toxixcity in male rats. The Journal of Animal and Plant Sciences, 25(1): 72-77.

Al-Okbi, S.Y., Mohamed, D.A., Hamed, T.E. and Esmail, R.S.H. (2014). Rice bran oil and pumpkin seed oil alleviate oxidative injury and fatty liver in rats fed high fructose diet. Polish Journal of Food and Nutrition Sciences, 64 (2): 127 133.

Al-Zuhair H., Abd EL-Fattah, A.A. and Abd El-Latif, H.A. (1997). Efficacy of simvastatin and pumpkin-seed oil in the management of dietary induced hypercholesterolemia. Pharmacological Research, 35: 403-408.

Andjelkovic, M., Camp, J.V., Trawka, A. and Verhe,'R. (2010). Phenolic compounds and some quality parameters of pumpkin seed oil. European Journal of Lipid Science and Technology,112: 208-217.

Azoz, H.A. and Raafat, R.M. (2012). Effect of lead toxicity on cytogenisity, biochemical constituents and tissue residue with protective role of activated charcoal and casein in male rats. Australian Journal of Basic and Applied Sciences, 6(7): 497-509.

Balubaid, S.O. (2011). The role of pumpkin extraction on the liver and kidney of mice previously treated with haloperidol during lactation. Journal of Life Sciences, 5: 7-14.

Bandyopadhyaya, A., Ghoshal, S. and Mukherjee, A. (2008). Genotoxicity testing of low-calorie sweeteners: aspartame, Acesulfame-K, and Saccharin. Drug and Chemical Toxicology, 31(4): 447-457. doi: 10.1080/01480540802390270.

Bataineh, Z.M., Hani, I.H. and Al-Alami, J.R. (2002). Zinc in normal and pathological human prostate gland. Saudi Medical Journal, 23(2): 218-220.

Belfield, A. and Goldberg, D.M. (1971). Normal ranges and diagnostic value of serum 5 'nucleotidase and alkaline phosphatase activities in infancy. Archives Disease Childhood, 46(250): 842-846.

Best, C.A., Cluette-Brown, J.E., Teruya, M., Teruya, A. and Laposata. M. (2003). Red blood cell fatty acid ethyl esters: a significant component of fatty acid ethyl esters in the blood. Journal of Lipid Research, 44: 612-620.

Campo, G.M., Avenoso, A., Campo, S., Nastasi, G., Traina, P., D'Ascola, A., Rugolo, C.A. and Calatroni, A. (2008). The antioxidant activity of chondroitin-4-sulphate, in carbon tetrachloride-induced acute hepatitis in mice, involves NF-kB and caspase activation. British Journal of Pharmacology, 155: 945-956. 
Chauhan, L.K., Pant, N., Gupta, S.K. and Srivastava, S.P. (2000). Induction of chromosome aberrations, micronucleus formation and sperm abnormalities in mouse following carbofuran exposure. Mutation Research, 465: 123-129.

Chiras, D. (2009). Environmental science. Jones and Bartlett Publishers, Sudbury, p. 394.

Eissa, F.I., El Makawy, A.I., EL-BAMBY, M.M. and Elhamalawy, O.H. (2018). Improved effect of pumpkin seed oil against the bisphenol-A adverse effects in male mice. Toxicology Reports, 5: 857-863.

Elfiky, S.A., Elelaimy, I.A., Hassan, A.M., Ibrahim, H.M. and Elsayad, R.I. (2012). Protective effect of pumpkin seed oil against genotoxicity induced by azathioprine. The Journal of Basic and Applied Zoology, 65: 289-298.

El-Nekeety, A.A., El-Kady, A.A., Soliman, M.S., Hassan, N.S. and AbdelWahhab, M.A. (2009). Protective effect of Aquilegia vulgaris L. against lead acetate-induced oxidative stress in rats. Food and Chemical Toxicology, 47: 2209-2215.

EL-Tantawy, W. H. ( 2016). Antioxidant effects of spirulina supplement against lead acetate-induced hepatic injury in rats. Journal of Traditional and Complementary Medicine, 6: 327-331.

Falck, A.J., Mooney, S., Kapoor, S.S., White, K.M., Bearer, C. and El Metwally, D., (2015). Developmental exposure to environmental toxicants. Pediatric Clinics, 62: 1173-1197.

Fruhwirth, G.O. and Hermetter, A. (2007). Seeds and oil of the Styrian oil pumpkin: Components and biological activities. European Journal of Lipid Science and Technology, 109: 1128-1140.

Garcon, G., Leleu, B., Marez, T., Zerimech, F., Haguenoer, J.M., Furon, D. and Shirali, P. (2007). Biomonitoring of the adverse effects induced by the chronic exposure to lead and cadmium on kidney function: usefulness of alpha-glutathione S-transferase. Science of the Total Environment, 377: 165172.

Gaskill, C.L., Miller, L.M. and Mattoon, J.S. (2005). Liver histopathology and liver and serum alanine aminotransferase and alkaline phosphatase activities in epileptic dogs receiving phenobarbital. Veterinary Pathology, 42(2): 147-160.

Gedik, C.M., Wood, S.G. and Collins, A.R. (1998). Measuring oxidative damage to DNA: HPLC and the comet assay compared. Free Radical Research, 29: 609615.

Giboney, P.T. (2005). Mildly elevated liver transaminase levels in the asymptomatic patient. American Family Physician, 71:1105-1110.

Gonick, H.C. (2011). Lead-binding proteins: a review, Journal of Toxicology, Article ID 686050, 10 pages, http://dx.doi.org/10.1155/2011/686050.

Gupta, C. (2007). Veterinary toxicology. In: Basic and Clinical Principles, second ed. Elsevier. 
Halliwell, B. (2007). Oxidative stress and cancer: have we moved forward? Biochemical Journal, 401: 1-11.

Hartwig, A. (1994). Role of DNA repair inhibition in lead and cadmium-induced genotoxicity: a review. Environmental Health Perspectives, 102(3): 45-50.

Hartwig, A., Schlepegrell, R. and Beyersmann, D. (1990). Indirect mechanism of lead-induced genotoxicity in cultured mammalian cells, Mutation Research, 241: 75-82.

Hashemi, J.M. (2013). Pumpkin seed oil and vitamin E improve reproductive function of male rats inflicted by testicular injury. World Applied Sciences Journal, 23(10): 1351-1359.

Kiran, B., Prabhakara, Y., Noble, T., Weddington, K., Sharada, R. and Rajanna, B. (2009). Lead-induced alteration of apoptotic proteins in different regions of adult rat brain. Toxicology Letters, 184: 56-60.

Knasmuller, S., Nersesyan, A., Misik, M., Gerner, C., Mikulits, W. and Ehrlich, V.C. (2008). Use of conventional and -omics based methods for health claims of dietary antioxidants: a critical overview. British Journal of Nutrition, ES3ES52.

Kodai, S., Takemura, S., Minamiyama, Y., Hai, S., Yamamoto, S., Kubo, S., Yoshida, Y., Niki, E., Okada, S., Hirohashi, K. and Suehiro, S. (2007). Sallyl cysteine prevents $\mathrm{CCl}_{4}$ - induced acute liver injury in rats. Free Radical Research, 41: 489-497.

Koedrith, P. and Seo, Y.R. (2011). Advances in carcinogenic metal toxicity and potential molecular markers. International Journal of Molecular Sciences, 12: 9576-9595.

Kulaitiene, J., Jariene, E., Danilcenko, H., Kita, A. and Venskutoniene, E. (2007). Oil pumpkins seeds and their quality. Poland Journal of Food and Nutrition Sciences, 57(4B): 349-352.

Kwon, S.Y., Bae, O.N., Nohm J.Y. and Kim, K. (2015). Erythrophagocytosis of leadexposed rrythrocytes by renal tubular cells: possible role in lead-induced nephrotoxicity. Environmental Health Perspectives, 123: 120-127.

Liu, C.M., Zheng, G.H., Ming, Q.L., Chao, C. and Sun, J.M. (2013). Sesamin protects mouse liver against nickel-induced oxidative DNA damage and apoptosis by the PI3KAKt pathway. Journal of Agricultural and Food Chemistry, 61: 1146-1154.

Lord, C.J. and Ashworth, A. (2012). The DNA damage response and cancer therapy. Nature, 481: 287-294.

Mathuria, N. and Verma, R.J. (2008). Ameliorative effect of curcumin on aflatoxininduced toxicity in serum of mice. Acta Poloniae Pharmaceutica - Drug Research, 65: 339-343.

Mohammed, G.M., Sedky, A. and Elsawy, H. (2017). A study of the modulating action of quercetin on biochemical and histological alterations induced by lead exposure in the liver and kidney of rats. Chinese Journal of Physiology, 60: 183-190. 
Naik, P. and Vijayalaxmi, K.K. (2009). Cytogenetic evaluation for genotoxicity of bisphenol-A in bone marrow cells of Swiss albino mice. Mutation Research, 676: 106-112.

National Toxicology Program (2003). Lead and Lead Compounds. NTP, Research Triangle Park, NC.

Nyam, K.L., Tan, C.P., Lai, O.M., Long, K. and Che, M.Y.B. (2009). Physicochemical properties and bioactive compounds of selected seed oil. LWT - Food Science and Technology, 42: 1396-1403.

OECD (1997). Test No. 474: Mammalian Erythrocyte Micronucleus Test.

Procida, G., Snatcher, B., Cateni, F. and Zaccchigna, M. (2012). Chemical composition and functional characterization of commercial pumpkin seed oil. Journal of Science and Food Agriculture, 93(5): 1035-1041.

Reitman, S. and Frankel, S. (1957). Acolorimetric method for the determination of serum glutamic oxalacetic and glutamic pyruvic transaminases. American Journal of Clinical Pathology, 28: 56-63.

Reyes, J.L., Molina-Jijón, E., Rodríguez-Muñoz, R., Bautista-García, P. and Debray-García, Y. (2013). Tight junction proteins and oxidative stress in heavy metals-induced nephrotoxicity. Biomed Res. Int., Article ID 730789, http://dx.doi.org/10.1155/2013/730789.

Santana, A.T., Guelfi, M., Medeiros, H.C.D., Tavares, M.A., Bizerra, P.F.V. and Mingatto, F.E. (2015). Mechanisms involved in reproductive damage caused by gossypol in rats and protective effects of vitamin E. Biological Research, 48(1): 43-50.

Sharma, B. Singh, S. and Siddiqi, N.J. (2014). Biomedical implications of heavy metals induced imbalances in redox systems, BioMed Research International, ID 640754, 26 pages http: //dx.doi. org/ 10.1155/ 2014/ 640754.

Stevenson, D.G., Eller, F.J., Wang, L., Jane, J.L., Wang, T. and Inglett, G.E. (2007). Oil and tocopherol content and composition of pumpkin seed oil in 12 cultivars. Journal of Agricultural and Food Chemistry, 55: 4005-4013.

Suleman, M., Khan, A.A., Hussain, Z., Zia, M.A., Roomi, S., Rashid, F., Iqbal, A. and Ishaq, R. (2011). Effect of lead acetate administered orally at different dosage levels in broiler chicks. African Journal of Environmental Science and Technology, 5(12): 1017-1026.

Urquiaga, I. and Leighton, F. (2000). Plant polyphenol antioxidants and oxidative stress. Biological Research, 33: 55-64.

Valko, M., Rhodes, C.J., Moncol, J., Izakovic, M. and Mazur, M.(2006). Free radicals, metals and antioxidants in oxidative stress-induced cancer. ChemicoBiological Interactions, 160: 1-40.

Xie, C., Wang, C., Wang, X. and Yang, X. (2013). Two modified RNA extraction methods compatible with transcript profiling and gene expression analysis for cotton roots. Preparative Biochemistry and Biotechnology, 43(5): 500-511. 
Zadak, Z., Hyspler, R., Ticha,' A., Hronek, M., Fikrova,' P., Rathouska,' J., Hrnciarikova, D. and Stetina, R. (2009). Antioxidants and vitamins in clinical conditions. Physiological Research, 58: 13-17.

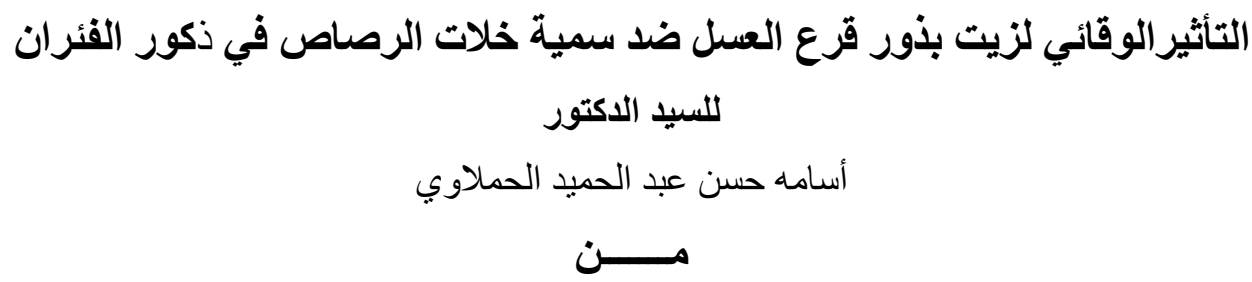

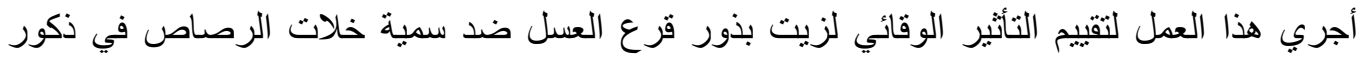

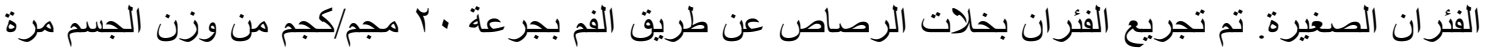

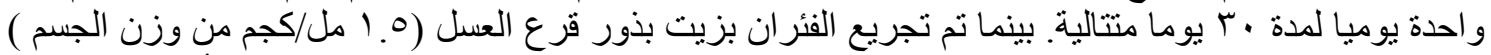

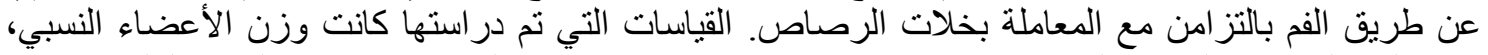

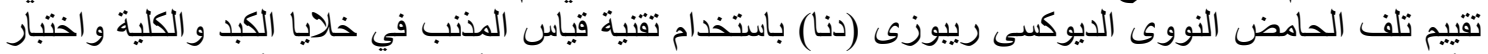

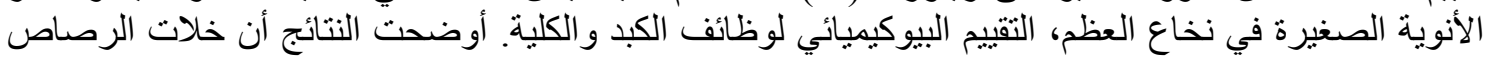

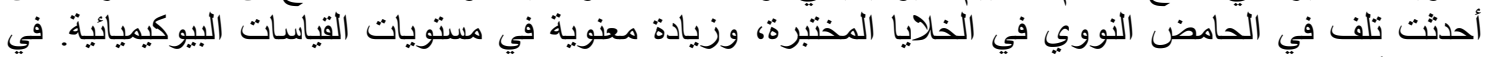

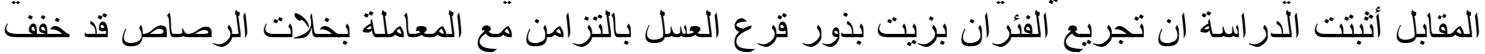

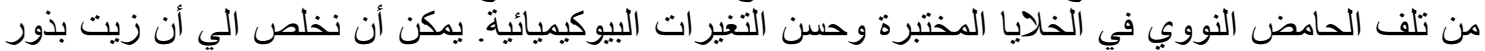
قرع العسل قد يكون له دور وقائي ضد سمية خلات الرصاص في في ذكور الفئر ان الصغيرة.

مفاتيح الكلمات: زيت بذور قرع العسل، خلات الرصاص، تلف الحامض النووي، الأنوية الصغيرة، تقنية قياس المذنب، القياسات البيوكيميائية. 